\author{
Małgorzata Dancewicz \\ ORCID: 0000-0003-4753-3464 \\ Uniwersytet Wrocławski
}

\title{
Performatywne misje simius sapiens. Coco Fusco na Planecie Małp*
}

\begin{abstract}
Zwierzęcy człowiek i ludzkie zwierzę to dwie strony tego samego pęknięcia, które nie może być naprawione od żadnej ze stron ${ }^{1}$.
\end{abstract}

Abstrakt: Artykuł dotyczy performansów kubańskiej artystki Coco Fusco, która w swoich interdyscyplinarnych projektach porusza zagadnienia związane z tożsamością narodową, etniczną, płciową i gatunkową. W cyklu performansów Observations of Predation in Humans: A Lecture by Dr. Zira, Animal Psychologist z 2013 roku Fusco, zainspirowana historią filmów z serii Planeta Matp oraz najnowszymi badaniami z zakresu prymatologii, przyjmuje postać dr Ziry, aby jako szympansica wykładać antropologię z nie-ludzkiej perspektywy.

Słowa-klucze: performans, prymatologia, strategie dokumentacji i wizualizacji w sztuce performans, Coco Fusco

Postawiona w przywołanym cytacie teza w kontekście misji sztuki powinna raczej zabrzmieć jako pytanie: czy wysiłek włożony w próbę przekroczenia antropomorfizmu może przyczynić się do zatarcia granicy między animalizacją człowieka a humanizacją zwierzęcia? Coco Fusco, urodzona w Nowym Jorku kubańsko-amerykańska artystka, w inspirowanym historią o Planecie Małp performansie Observations of Predation in Humans: A Lecture by Dr. Zira, Animal Psychologist realizuje swoją misję poprzez gest przekraczania granicy między tym, co ludzkie, a tym, co zwierzęce. Zadanie, jakie sobie stawia, to zredukowanie różnic między sobą jako performerką, kobietą a dr Zirą — małpą, samicą.

${ }^{*}$ Tekst powstał w wyniku realizacji projektu badawczego nr 2014/15/N/HS2/03858 pod tytułem Performans postmedialny. Wspótczesny kontekst technologiczny działań performatywnych, finansowanego ze środków Narodowego Centrum Nauki.

${ }^{1}$ G. Agamben, Otwarte, przeł. P. Mościcki, „Krytyka Polityczna” 2018, nr 15, s. 129. 
„Szlachetne goryle, uczone orangutany, subtelne szympansy, o małpy! Pozwólcie, że zwróci się do was człowiek. Wiem, że mój wygląd jest groteskowy, kształt — odpychający, profil — zwierzęcy, zapach — odrażający, a kolor skóry — wstrętny"2. Te słowa kieruje do nadzwyczajnego zgromadzenia małp główny bohater książki Planeta matp Pierre'a Boulle'a. Jego wystąpienie ma udowodnić, że jako zwierzę ma nie tylko zdolność posługiwania się językiem, ale też umiejętność logicznego myślenia, a może nawet „duszę”. Na Planecie Małp to człowiek jest bezrozumnym zwierzęciem, a tym, co odróżnia małpy od ludzi, jest świadomość przejawiająca się w zdolności do posługiwania się językiem. Ulisses, francuski dziennikarz, który ląduje na obcej planecie, usiłuje znaleźć rozwiązanie zagadki małpiej ewolucji. Podejrzewa, że rozum może wcielić się w dowolnie wybraną materię. Forma niewiele znaczy. Dusza, jak pisze Boulle, może się ujawnić w człowieku lub małpie, w zależności od mniej lub bardziej sprzyjających warunków ewolucyjnych. W tym specyficznym esencjalizmie kryje się pewnego rodzaju anachronizm powieści Boulle'a, w której człowiek i małpa zostają zamienione miejscami, jednak sama granica między tym, co ludzkie, i zwierzęce pozostaje nienaruszona. To, kto jest w tym układzie niewolnikiem, kto barbarzyńcą, a kto obcym, zależy wyłącznie od obranej perspektywy. Raz są to małpy, innym razem ludzie.

Historyczne spojrzenie na taksonomię ssaków naczelnych ukazuje dwa ścierające się z sobą poglądy. Klasyczne podejście umieszcza człowieka na szczycie drabiny gatunkowego rozwoju, wyróżniając go spośród całej reszty zwierzęcego świata. Współczesna filogeneza i antropogeneza wskazują jednak na wiele wspólnych genetycznie i morfologicznie cech, które umieszczają nas w jednym rzędzie ssaków naczelnych, obok szympansów, goryli i orangutanów. Zmiana w taksonomii jest widoczna nie tylko na poziomie ssaków naczelnych, lecz dotyczy także podziału na biologię ożywioną i nieożywioną. Granica, która niegdyś oddzielała to, co uważane było za świat nieożywiony i ożywiony, ludzi, zwierzęta, minerały, wirusy, bakterie, plastiglomeraty ${ }^{3}$, przemieszcza się, obejmując zbiory i podzbiory wszystkiego, co występuje na Ziemi ${ }^{4}$. Od czasu kiedy Boulle napisał swoją powieść w 1963 roku, staliśmy się znacznie bogatsi — nie tylko o wciąż pogłębianą wiedzę z zakresu fizjologii i psychologii zwierząt, ale też doświadczenie i zaangażowanie wypracowane w kręgu animal studies.

2 P. Boulle, Planeta malp, przeł. K. Pruska, K. Pruski, Warszawa 1980, s. 113.

${ }^{3}$ Określenie na połączenia plastiku ze skałami wulkanicznymi, koralowcami i muszlami. Zob. M. Bakke, Pandemiczne wspólnoty przenoszone droga plastikowa, [w:] Pandemia. Nauka, sztuka, geopolityka, red. M. Iwański, J. Lubiak, Szczecin 2018, s. 146-147.

${ }^{4}$ Sama klasyfikacja hominidów jest kwestią sporną i wciąż dyskutowaną, nie tylko z powodów kulturowych, lecz między innymi dzięki odkryciu struktury DNA i rozpoczętym na nowo badaniom nad odnalezionymi szczątkami wymarłych gatunków „pierwszych ludzi”. Zob. M. Goodman et al., Where DNA sequences place Homo sapiens in a phylogenetic classification of primates, [w:] Humanity from African Naissance to Coming Millennia, red. P.V. Tobias et al., Firenze 2001, s. 279-289. 
W 1975 roku Peter Singer swoją publikacją Wyzwolenie zwierzą $t^{5}$ podjął temat szowinizmu gatunkowego, dając podbudowę filozoficzną do założenia wielu organizacji działających na rzecz praw zwierząt, między innymi Great Ape Project $(\mathrm{GAP})^{6}$. GAP powstało w 1994 roku, równolegle z książką Petera Singera i Paoli Cavalieri o tym samym tytule, która stała się manifestem organizacji ${ }^{7}$, a sam Singer został jej honorowym przewodniczącym. GAP ma za zadanie chronić prawa czterech głównych ssaków naczelnych: orangutanów, goryli, szympansów i bonobo, zapewniać im prawo do życia, wolności od klatek i eksperymentów medycznych.

Ulisses, główny bohater powieści Planeta matp, pisał w swoim pamiętniku, że stosunek małp do ludzi był radykalnie różny: „Uczeni podzielili się na dwa obozy. Jedni utrzymywali, że zwierzę jest całkowicie pozbawione duszy, drudzy, że między psychiką zwierząt i małp istnieje różnica tylko w stopniu rozwoju"8. Zwierzęciem, o którym pisze Ulisses, jest tu człowiek. To ludzie są poddawani psychologicznym i medycznym eksperymentom, od badań odruchów bezwarunkowych w duchu Pawłowa po dokonywanie wiwisekcji. Człowiek - Ulisses Mérou - uznany za wyjątkowy przykład mówiącego zwierzęcia zostaje zapoznany z „humanitarnymi” metodami prowadzenia badań, których celem, oprócz poznania anatomii ludzi, jest wyjaśnienie zagadki pochodzenia małp. Większość operacji przeprowadza się tu w pełnej narkozie. W nielicznych wyjątkach, które mają na celu poznanie funkcjonowania ośrodków bólu i ośrodków nerwowych, stosuje się znieczulenie. Neuronaukowiec szympans Helius, oprowadzając Ulissesa po laboratorium, zaznacza, że „Wszystkie operacje [...] są teraz przeprowadzane na uśpionych okazach - mocno podkreślił ten fakt, dowodzący wysokiego stopnia rozwoju małpiej cywilizacji, która zatroszczyła się o wyeliminowanie wszelkich niepotrzebnych cierpień, nawet jeśli chodzi o ludzi”" . Niektórym małpim uczonym intuicja podpowiada niebezpieczną dla powszechnie obowiązującego, fundamentalistycznego podejścia, hipotezę, że małpy mogłyby w prostej linii rozwojowej wywodzić się od człowieka.

W antropomorficznym geście Boulle, zamieniając miejscami małpy i ludzi, zadaje pytanie o prawo człowieka do podporządkowywania sobie natury oraz o źródła dążenia do wiedzy, moralności i odpowiedzialności za przyszłość. Powieść można traktować jako antycypacyjne zapiski o antropocenie. Autor kreśli wizję przyszłości, na którą człowiek, bezwiednie eksploatując zasoby ,naszej planety", w pełni sobie zasłużył. Utrata panowania na Ziemi nie jest tu jednak konsekwencją destrukcyjnego wpływu ludzi na biosferę, ale raczej ich marazmu, miz-

\footnotetext{
5 P. Singer, Wyzwolenie zwierząt, przeł. A. Alichniewicz, A. Szczęsna, Warszawa 2004.

${ }^{6}$ https://www.projetogap.org.br/en/history/ (dostęp: 20.07.2019).

${ }^{7}$ P. Cavalieri, P. Singer, The Great Ape Project: Equality Beyond Humanity, New York 1994.

8 P. Boulle, op. cit., s. 107-108.

${ }^{9}$ Ibidem, s. 152.
} 
antropii i zaniku potrzeby komunikacji społecznej, o czym dowiadujemy się od ludzi w trakcie przeprowadzanych na nich w laboratorium encefalicznym badań.

Historia przejęcia władzy nad światem przez małpy stała się inspiracją kinematografii i kultury masowej, które przekształciły ją w rodzaj współczesnego dystopijnego mitu. King Kong, który jest jedną z najbardziej rozpoznawalnych postaci filmowych, oraz małpy z filmowej serii Boulle'a uosabiają zagrażających człowiekowi antybohaterów. Przeciwnie do wzorców pojawiających się w popkulturze literatura realizuje temat małp w odmienny sposób. W takich tekstach, jak Planeta matp Boulle (1963), Matpa i duch Aldousa Huxleya (1948), The Apes Edena Phillpottsa (1929) czy Sprawozdanie dla Akademii Franza Kafki $(1917)^{10}$, pojawienie się małpy jako postaci symbolicznej, ewolucyjnie bliskiej człowiekowi, kulturowo jednak odległej od uważanej za „normatywną” ludzkiej cywilizacji, jest pełnym wyrazu zabiegiem retorycznym działającym przeciwko wyobcowaniu, rasizmowi, kolonializmowi i wyzyskowi społecznemu ${ }^{11}$.

Performans Coco Fusco przewartościowuje kategorie znaczeniowe zaczerpnięte z kultury popularnej. Zarówno literacki pierwowzór, jak i ekranizacja Planety matp ${ }^{12}$ przedstawiają mroczną, spekulatywną wizję ewolucji naczelnych, w której interesy biologiczne małp i ludzi wzajemnie się wykluczają. Coco Fusco dąży do otwarcia relacji między tym, co ludzkie i nie-ludzkie, i przyjęcia perspektywy „wkluczenia” siebie nawzajem, do połączenia perspektywy małpy i kobiety.

${ }^{10} \mathrm{Na}$ szczególną uwagę zasługuje podobieństwo wystąpienia głównego bohatera książki Boulle'a przed zgromadzeniem małp, przywołane we wstępie niniejszego tekstu, do wystąpienia przed członkami Akademii głównego bohatera opowiadania Franza Kafki. Rotpeter, bohater Sprawozdania dla Akademii, to małpa, która przeszła transformację w człowieka. Rotpeter przejął ludzkie zachowania, wierząc, że upodobnienie się do ludzi umożliwi mu wyjście z klatki. Wątek naśladownictwa jest o tyle istotny, że u Boulle'a ewolucja małp przebiega właśnie dzięki naśladowaniu ludzi, które w konsekwencji prowadzi do rozwoju myśli technologicznej i kulturowej. Wiemy to stąd, że cała historia w książce umieszczona jest w klamrze. Wszystkie przeżycia i przemyślenia głównego bohatera są odczytywane z jego pamiętnika przez parę szympansów, która znajduje jego tekst w butelce. Szympansy, które zamykają klamrą opowieść, lecą zaawansowanym technologicznie statkiem kosmicznym. Czytają wspomnienia głównego bohatera jak tekst science fiction, napisany przez małpę o wyjątkowo bujnej wyobraźni, ponieważ nie wierzą, że mógłby to napisać człowiek. Z kolei w Sprawozdaniu dla Akademii małpa Rotpeter upodabnia się do ludzi przez ich naśladownictwo, jednak Kafka ukazuje ten proces jako destrukcyjny. Zob. Ż. Nalewajk, Ironia jako alternatywa rozpaczy. Krytyka kultury w Sprawozdaniu dla Akademii Franza Kafki, „Tekstualia” 2008, nr 3, s. 67-78.

${ }^{11}$ G. Westfahl, The Greenwood Encyclopedia of Science Fiction and Fantasy: Themes, Works, and Wonders, t. 1, London 2005, s. 43-45.

12 Planeta Matp, reż. F.J. Schaffner, USA 1968.

Prace Kulturoznawcze 23, 2019, nr 2-3

(C) for this edition by CNS 


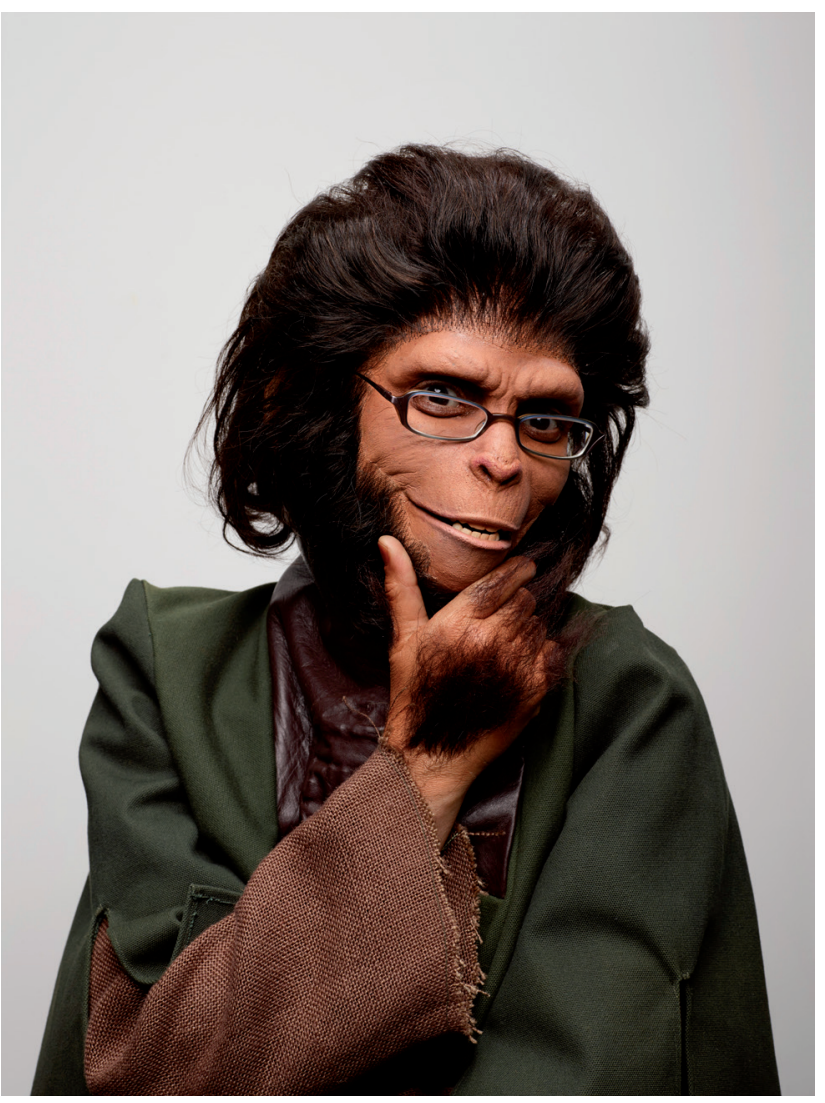

Ilustracja 1. Portret Coco Fusco z performansu Observations of Predation in Humans: A Lecture by Dr. Zira, Animal Psychologist, 2013

Źródło: Walker Art Center, fot. Gene Pittman.

\section{Performatywny wykład jako spin-off}

Coco Fusco to performerka, która w swoich interdyscyplinarnych projektach porusza zagadnienia związane z tożsamością narodową, etniczną, płciową i gatunkową. Doktor Zira to psycholożka i weterynarka, szympansica zajmująca się badaniem zachowań ludzkich na Planecie Małp. Fusco w cyklu performansów Observations of Predation in Humans: A Lecture by Dr. Zira, Animal Psychologist, zainspirowana historią filmów z serii Planeta Matp, przyjmuje postać Ziry. Jako szympansica wykłada antropologię, której główne założenia opierają się na badaniach materiałów filmowych oglądanych w popularnych stacjach telewizyjnych. Związki między literackim pierwowzorem, serią filmów i performansem zasadzają się na kontynuacji lub wa- 
riacji na temat głównych wątków narracyjnych. Performans Fusco jest więc swego rodzaju spin-offem kinowej serii nakręconego w latach siedemdziesiątych ubiegłego wieku cyklu. Doktor Zira to obok męskiego, ludzkiego protagonisty Taylora główna postać filmu Planeta Matp. Jest inteligentna, empatyczna, skrajnie liberalna. Walcząc z naukowym fundamentalizmem, jest otwarta na nową wersję ewolucji małpiego gatunku. Jako empirystka, specjalistka od psychologii zwierzęcej, prowadzi obserwacje i eksperymenty behawioralne, aczkolwiek jednocześnie przeprowadza lobotomie, wiwisekcje i inne doświadczenia na żywych ludziach. Przyznaje się do tego właśnie przed ludźmi w trakcie przesłuchań Prezydenckiej Komisji Śledczej w trzeciej części filmowego cyklu, pod tytułem Ucieczka z Planety Matp ${ }^{13}$.

Przede wszystkim dr Zira jest jednak kobietą. To fakt nie bez znaczenia. Donna Haraway, analizując serię dokumentów telewizyjnych dotyczących badań prymatologów, których produkcję w latach sześćdziesiątych rozpoczęło National Geographic, zwraca uwagę na ogólnie obowiązującą, promowaną przez stację politykę wizualizacji badań nad ssakami naczelnymi, w której dominuje „strategia National Geographic" — w dalekiej afrykańskiej lub indonezyjskiej dżungli biała kobieta z gracją przełamuje przepaść między ludzkim a zwierzęcym, czego symbolem stały się tak zwane Aniołki Leakeya. Louis Leakey, kenijski antropolog, który jako pierwszy postawił hipotezę dotyczącą afrykańskiego rodowodu człowieka, uznał, że paleontologia może mieć wiele wspólnego z prymatologią, a badając zachowania małp człekokształtnych, możemy uzupełniać wiedzę na temat naszych ludzkich przodków. W 1958 roku w okolicach Nairobi założył centrum badań Tigoni Primate Research Center, w którym zatrudniał do badań głównie kobiety jako bardziej empatyczne, cierpliwe i wyrozumiałe od mężczyzn. W większości były to też osoby bez wcześniejszego przygotowania naukowego z zakresu prymatologii. Do najbardziej znanych badaczek wspieranych na początku ich naukowej drogi przez Leakeya należą Jane Goodall, Birute Galdikas i Dian Fossey. Goodall wyspecjalizowała się w badaniach szympansów, Galdikas zajęła się orangutanami, a Fossey zaangażowała się w badania nad gorylami górskimi ${ }^{14}$.

Film Ucieczka z Planety Matp opowiada historię brzemiennej Ziry i jej męża Corneliusa, którzy ratują się przed wojną na Planecie Małp, emigrując do przeszłości - na Ziemię późnych lat sześćdziesiątych XX wieku. Planeta Małp jest wówczas jeszcze pod panowaniem człowieka. Małpia rodzina, początkowo wielbiona przez Amerykanów i rozsławiana przez mass media, spełnia swoje pokojowe posłannictwo, uczestnicząc w odczytach, oficjalnych nadaniach imienia i innych reprezentacyjnych okazjach. Kiedy jednak okazuje się, że tam, skąd przybywa Zira, czyli w przyszłości, Ziemia zamieszkiwana jest przez rozumne małpy, które zajęly miejsce ludzi, myśląca i mówiąca szympansica ze swoim nie-

13 Ucieczka z Planety Matp, reż. D. Taylor, USA 1971.

14 D. Haraway, Primate Visions: Gender, Race, and Nature in the World of Modern Science, New York-London 1989, s. 133-185. 
narodzonym jeszcze potomkiem staje się realnym zagrożeniem, które trzeba zlikwidować. Małpy muszą ratować się ucieczką. W trakcie obławy Zira rodzi syna. Cała trójka zostaje złapana; Cornelius zostaje zastrzelony. Nie wiemy natomiast, czy Zira i jej dziecko, które sama wrzuca do wody, również umierają.

Fabuła filmu i zagadka jego zakończenia są podstawą przedstawionej w performansie historii. Coco Fusco przy realizacji wykładów dr Ziry współpracowała z Donną Haraway, której wystąpienie przez Skype'a rozpoczynało performans ${ }^{15}$. Ze wstępu Haraway dowiadujemy się, że Zira nie zginęła w trzeciej części filmu, ale przez dwadzieścia lat, żyjąc w ukryciu, obserwowała ludzkie zachowania w telewizji i internecie. Na podstawie materiałów, które oglądała w tym czasie, zdecydowała się na cykl wykładów na temat zachowań ludzi. Decyzję o wyjściu z ukrycia podjęła dopiero, kiedy dowiedziała się o podpisaniu przez wybitnych naukowców The Cambridge Declaration on Consciousness, deklaracji podjętej w czasie The First Annual Francis Crick Memorial Conference ${ }^{16}$ pod tytułem Consciousness in Humans and Non-Human Animals, w której stwierdza się, że podobnie jak ludzie również nie-ludzkie zwierzęta mają świadomość ${ }^{17}$.

\section{Wizualizacja radykalnej obecności}

Działanie Coco Fusco zostało przygotowane na zaproszenie do udziału w wystawie Radical Presence: Black Performance in Contemporary Art w 2013 roku w The Studio Museum in Harlem w Nowym Jorku ${ }^{18}$. Była to pierwsza retrospektywna wystawa afroamerykańskich artystów tworzących od lat sześćdziesiątych black performance art ${ }^{19}$. O ich obecności w obiegu sztuk wizualnych kurator projektu Cassel Oliver pisał: „Czarne ciało jest ciałem, które zostało przymuszone do bycia celem publicznego spojrzenia i wyposażone w przymusową widoczność. Zostało stworzone, aby być poddanym obserwacji" ${ }^{20}$. Ta sytuacja bycia widzianym, w obliczu świadomej odmienności, to wystawienie ciała na pole walki z cu-

15 https:/www.dailyserving.com/2015/02/from-the-archive-coco-fusco-observations-ofpredation-in-humans-at-the-studio-museum-in-harlem/ (dostęp: 30.07.2019).

$16 \mathrm{http}: / /$ fcmconference.org (dostęp: 29.07.2019).

${ }^{17}$ Deklaracja przyjęta została w 2012 roku. Zob. http://fcmconference.org/img/CambridgeDeclarationOnConsciousness.pdf (dostęp: 30.07.2019).

18 Wystawa składała się z ponad stu prac trzydziestu sześciu artystów. Zob. katalog wystawy Radical Presence: Black Performance in Contemporary Art, red. Y. Backer et al., Contemporary Arts Museum, Houston 2013.

$19 \mathrm{https}$ ://walkerart.org/calendar/2014/radical-presence (dostęp: 23.07.2019).

20 „The black body [...] is a body that has been forced into the public spotlight and given a compulsory visibility. It has been made to be given to be seen" — http://moussemagazine.it/radical-presence-museumstudioharlem-newyork/ (dostęp: 28.07.2019). 
dzym spojrzeniem, to coś, o czym Raimund Hoghe, za Pier Paolo Pasolinim, pisał: „Wrzucam moje ciało na pole walki”" 21 .

Odczuwane silne emocje ${ }^{22}$, jakie u odbiorcy wzbudza ciało „czarne”, „upośledzone”, ,zwierzęce”, pozwala temu ciału uzyskać podmiotowość i autonomię. Tę autonomię Coco Fusco uzyskuje dzięki nakładaniu maski. W wykładach dr Zira przywdziewa maskę małpy, a małpa, którą się staje, nakłada kobiecy strój i makijaż, dochowując zasad poprawności kobiecego/ludzkiego wizerunku. Z podobną sytuacją mamy do czynienia w wypadku działań Guerilla Girls ${ }^{23}$, kiedy anonimowe artystki w maskach małp analizują rolę kobiet w sztuce. Ich najbardziej rozpoznawalna praca to plakat, na którym zadają pytanie o to, „czy kobieta musi być naga, aby wejść do muzeum?"24. Bezpośrednią przyczyną założenia ruchu Guerilla Girls i ich pierwszego manifestu była zorganizowana w nowojorskim MoMA w 1984 roku wystawa pod tytułem An International Survey of Recent Painting and Sculpture $^{25}$, na której wśród stu sześćdziesięciu dziewięciu prezentowanych artystów było jedynie trzynaście kobiet. Zarówno dla Guerilla Girls, jak i dla Coco Fusco sztuka niesie możliwość krytyki systemowej i instytucjonalnej. Nałożenie maski małpy umożliwia $\mathrm{w}$ sensie formalnym bycie anonimowym względem norm cywilnoprawnych, regulujących „partyzanckie” metody przekazywania treści w sztuce. Jednocześnie daje artystkom możliwość bycia dostrzeżoną jako podmiot, a nie jako przedmiot spojrzenia. W przypadku Guerilla Girls istotne staje się również działanie w grupie, kolektywie, w którym nadrzędnym celem jest realizacja konkretnego projektu, a nie splendor, jaki wiąże się z indywidualnym autorstwem dzieła sztuki.

Fusco przez przybieranie różnych ról w performansach kreuje swoją tożsamość jako tożsamość Innego. W jednym z jej najbardziej rozpoznawalnych projektów Two Undiscovered Amerindians Visit the West ${ }^{26}$, zrealizowanym wspólnie z Guillermo Gómez-Peñą w 1992 roku, staje się przedstawicielką nieistniejącego plemienia. Fusco i Gómez-Peña w związku z obchodami stulecia odkrycia przez Krzysztofa Kolumba Ameryki przez trzy dni prezentowali siebie w klatce umieszczonej na placu Kolumba w Madrycie. Przedstawiani byli jako żywe eksponaty, nowo odkryte „pierwotne okazy” Indian meksykańskich. Tym samym odwoływali się do praktyki wystawiania na pokaz publiczny — na targach, dworach i w ogrodach zoologicznych — rdzennych mieszkańców kolonizowanych krajów, funkcjonującej w Euro-

${ }^{21}$ Je jette mon corps dans la bataille, http://www.raimundhoghe.com/fr/fr handicaps.html (dostęp: 28.07.2019).

${ }^{22}$ Intensywność w tym wypadku może być utożsamiana z afektem. Zob. B. Massumi, Autonomia afektu, przeł. A. Lipszyc, „Teksty Drugie” 2013, nr 6, s. 112-135.

${ }^{23} \mathrm{https}: / / w w w . g u e r r i l l a g i r l s . c o m / \#$ open (dostęp: 29.07.2019).

${ }^{24}$ Do women have to be naked to get into The Met Museum?, https://www.youtube.com/watch?v= EHVBZh5HBgc\&eurl=http\%3A\%2F\%2Fwww.woostercollective.com\%2F\%2F (dostęp: 9.08.2019). Na temat Coco Fusco i Guerilla Girls zob. C. Fusco, Taste as a political matter: Coco Fusco on the Guerrilla Girls, https://walkerart.org/magazine/coco-fusco-guerrilla-girls (dostęp: 29.07.2019).

${ }^{25}$ Zob. https://www.moma.org/calendar/exhibitions/2220?locale=en (dostęp: 9.08.2019).

${ }^{26} \mathrm{https} / / /$ www.cocofusco.com/two-undiscovered-amerindians (dostęp 29.07.2019). 
pie aż do XX wieku ${ }^{27}$. Performerzy postrzegani przez nieświadomych odbiorców jako odnalezione eksponaty nieistniejącego plemienia Indian jednocześnie się nimi stają. To spojrzenie zza krat nadaje im egzotyczną, mniejszościową, nową tożsamość $^{28}$. Fusco i Gómez-Peña zamknięci w klatce i podróżujący po różnych, typowych dla wystawiennictwa kolonialnego miejscach karmieni byli przez ten czas bananami i wyprowadzani na smyczach, opłacani za możliwość zrobienia sobie z nimi zdjęcia czy dotknięcia ich uwięzionych ciał.

W innym performansie - Dolores form 10 to 22 z 2001 roku — Fusco wciela się w pracownicę maquiladora — jednego z wielu przedsiębiorstw, które dzięki przepisom NAFTA działają w Meksyku na specjalnych zasadach. Omijając płacenie cła i podatków, jednocześnie wykorzystują nisko opłacanych pracowników. Dolores, autentyczna postać, planowała utworzenie związków zawodowych w fabryce, w której pracowała. Jej pracodawca, Jorge, którego w performansie odgrywał Ricardo Dominguez, miał do tego nie dopuścić, przetrzymując ją w zamknięciu przez dwanaście godzin i zmuszając do podpisania wypowiedzenia. Przez dwanaście godzin Fusco i Dominguez odgrywali w czasie rzeczywistym sytuację $\mathrm{z}$ maquiladora $\mathrm{w}$ ciasnym pomieszczeniu helsińskiej galerii współczesnej Kias$\mathrm{ma}^{29}$. Performans rejestrowany był za pomocą kamery przemysłowej, a następnie dystrybuowany w innych galeriach jako instalacja wideo.

W wielu projektach performerki pojawia się element bycia obserwowaną, voyeryzmu i sprawowania kontroli, stąd też częste użycie dokumentacji wideo, pełniącej funkcję zewnętrznego obserwatora i świadka. Tworzenie filmowych dokumentacji oraz ich samodzielna, autorska produkcja jest również ważnym elementem emancypującym od władzy normatywnego spojrzenia. Fusco, kiedy mówi o wykładach dr Ziry, bezpośrednio odwołuje się do doświadczenia bycia w klatce z Two Undiscovered Amerindians Visit the West, które było także zarejestrowane jako trzydziestominutowy wideodokument. Wykłady dr Ziry funkcjonują jako streaming TED, dostępny na stronie Video Data Bank ${ }^{30}$.

„Wcielanie się" w rolę jest w performansach Coco Fusco jednym ze sposobów dokumentacji, przedłużaniem realnie istniejących historii i bytów. Przybieranie ról i dokumentacja performansu są zatem podobnym zabiegiem, stanowią strate-

27 Na temat „ludzkiego zoo” zob. L.A. Sánchez-Gómez, Human zoos or ethnic shows? Essence and contingency in living ethnological exhibitons, „Culture \& History Digital Journal” 2, 2013, nr 2, s. 2-25; oraz Human Zoos: Science and Spectacle in the Age of Colonial Empires, red. P. Blanchard et al., Liverpool 2008.

${ }^{28}$ W 2001 roku Coco Fusco wydała książkę dotyczącą postkolonialnych strategii w sztuce i polityce, uwzględniając refleksje o swoim kubańskim pochodzeniu, wspomnienia z dzieciństwa i rodzinne historie. Zob. eadem, The Bodies That Were Not Ours: And Other Writings, London-New York 2001.

29 C. Fusco, On-line simulations/real-life politics: A discussion with Ricardo Dominguez on staging virtual theatre, ,TDR/The Drama Review” 47, 2003, nr 2, s. 151-162.

30 TED Ethology: Primate Visions of the Human Mind - Coco Fusco, http://www.vdb.org/ titles/ted-ethology-primate-visions-human-mind (dostęp: 15.09.2019). 
gie upamiętniania, które mają za zadanie zachowanie historii, zarówno realnych, jak i wyobrażonych. Działania Coco Fusco są mimetycznymi performansami, w których społecznie zaangażowany performer staje się nie swoim własnym, ale obcym, uobecnionym ciałem świadka, Innego - ciała czarnego, ciała kobiety, ciała zwierzęcia. Ucieleśnienie radykalnej obecności w Observations of Predation in Humans staje się skuteczne właśnie dzięki zintensyfikowaniu obcości - zestawieniu ciała człowieka jako małpy i samicy szympansa jako kobiety.

\section{Geneza Planet Małp}

Podstawową inspiracją serii wykładów przygotowanych przez Fusco było zagadnienie dotyczące biologicznych i kulturowych podstaw agresji u ludzi. Doktor Zira studiowała zarówno ludzkie zachowania, jak i struktury neuronalne. W swoich wykładach rozważa przyczyny występowania drapieżnictwa u ludzi, które opisuje w ten sam sposób, w jaki naukowcy wypowiadają się o agresji u zwierząt. Główną kwestię Planety Matp - książki, ekranizacji i performansu — można by sprowadzić do jednego, podstawowego pytania: „skąd pochodzi moralność?”31. Łacińskie słowo simius, simia (małpa) ma ten sam źródłosłów co simile, simulare oznaczające podobieństwo, symulację. Jednym z głównych zagadnień literackiego pierwowzoru Planety Matp jest pytanie o to, w jaki sposób powstaje kultura rozumiana jako system wartości. Ulisses, zbierając coraz to nowe obserwacje o małpiej cywilizacji, ma niesłabnącą nadzieję na to, że małpy nie wymyśliły niczego samodzielnie i rozwinęły swój język, sztukę i naukę właśnie dzięki symulacji zachowań człowieka. Współczesna neurokognitywistyka społeczna ${ }^{32}$ łączy metody badań neuronaukowych, psychologii i socjologii, próbując zdiagnozować zależności między działaniem mózgu i umysłu w procesach tworzących wzajemne relacje między ludźmi. Jedną z hipotez stawianych $\mathrm{w}$ celu zrozumienia powiązań społecznych, a zatem i umiejętności tworzenia kultury, jest hipoteza neuronów lustrzanych zaproponowana przez Giacoma Rizzolattiego i Vittoria Gallesego ${ }^{33}$. Zgodnie z nią ssaki na-

${ }^{31}$ Specyficzny pogląd na pochodzenie moralności ma prymatolog Frans de Waal. W swojej książce Malpy i filozofowie. Skąd pochodzi moralność obala on teorię fasady, według której ludzie są z natury źli, a to, co robią altruistycznie, czynią wyłącznie dla własnej korzyści. Na podstawie obserwacji zachowań małp człekokształtnych, zwłaszcza bonobo, stwierdza, że empatia i altruizm to cechy dziedziczone ewolucyjnie od zwierząt. Zob. idem, Matpy i filozofowie. Skąd pochodzi moralność, przeł. B. Brożek, M. Furman, Kraków 2019.

32 P. Przybysz, Wprowadzenie. Poznanie społeczne: lustrzane neurony, automatyzm a refleksje, rozpoznawanie umystów, [w:] Formy aktywności umystu. Ujęcia kognitywistyczne, t. 2, red. A. Klawiter, Warszawa 2009.

33 Teorię neuronów lustrzanych rewiduje Gregory Hickok, który nie podważa ich istnienia, ale proponuje zachowanie ostrożności w przypisywaniu im tak skomplikowanych funkcji, jakie zakładali Rizzolatti i Gallese. Zob. G. Hickok, Mit neuronów lustrzanych, przeł. K. Cipora, A. Machniak, Kraków 2016. 
czelne mają w płacie czołowym mózgu obszar nazwany przez badaczy neuronami lustrzanymi. Obszar ten aktywuje się zarówno w czasie patrzenia na wykonywanie czynności przez innych, jak i podczas samodzielnego wykonywania tej samej czynności, co oznacza, że symulowanie jest ważnym determinantem działania w sensie osobniczym i społecznym. W uproszczeniu, gdyby przyjąć, że hipoteza ta jest prawdziwa, niepokoje Ulissesa mogłyby być uzasadnione - małpy byłyby zdolne do przejęcia ludzkich zachowań, a z czasem i do wytworzenia wyrafinowanej kultury, sztuki i technologii, co zresztą sugeruje nam zakończenie książki ${ }^{34}$.

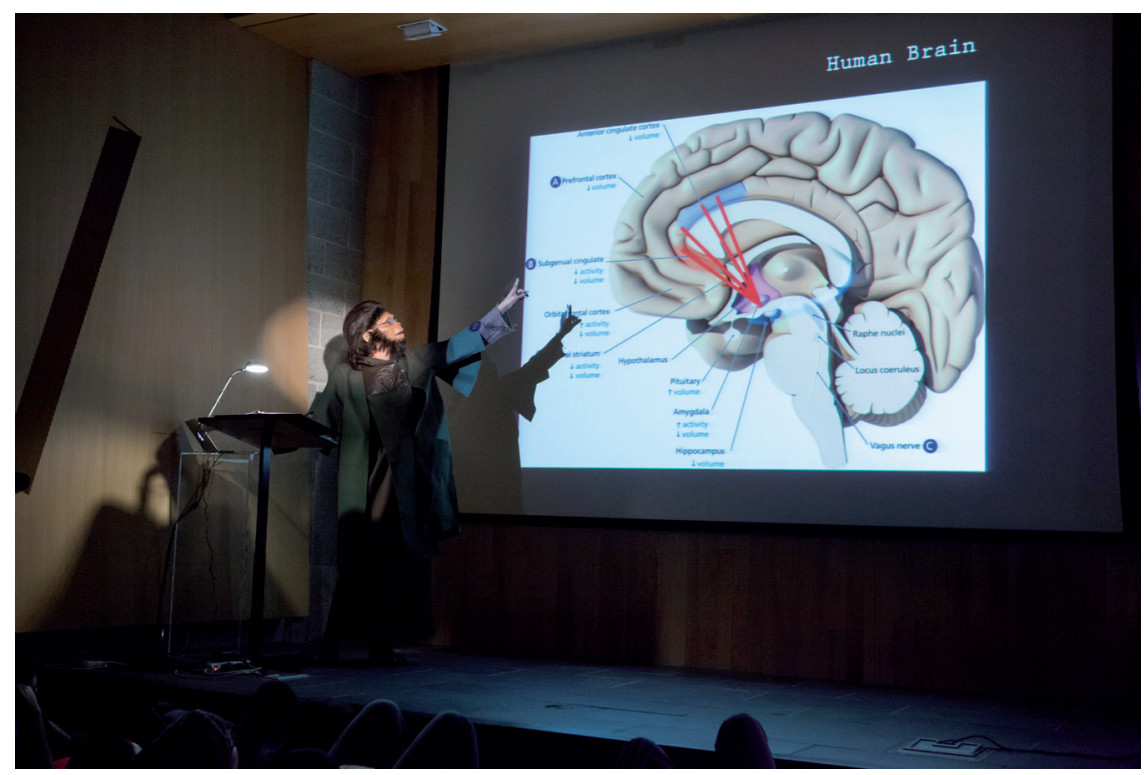

Ilustracja 2. Coco Fusco, Observations of Predation in Humans: A Lecture by Dr. Zira, Animal Psychologist, 2013. Performans w the Studio Museum in Harlem, Nowy Jork 2013

Źródło: fotografia dzięki uprzejmości artystki.

${ }^{34}$ Interesujący komentarz na temat neurologicznych podstaw moralności ssaków można znaleźć we wspomnianej pracy de Waala Matpy i filozofowie. W komentarzu do tej propozycji Peter Singer podważa jednak wyciąganie wniosków dotyczących pochodzenia i natury moralności na podstawie badań neuroobrazowania pracy mózgu - F. de Waal, op. cit., s. 171-183. Niemniej jednak neurologia staje się inspiracją wielu utopijnych i dystopijnych wersji przyszłości, między innymi nowej serii filmów, rozpoczętej Geneza Planety Matp, w której małpy buntują się przeciwko ludziom w wyniku powikłań występujących w trakcie prowadzonych na szympansach neurologicznych eksperymentów zmierzających do wynalezienia leku na chorobę Alzheimera. Warto zaznaczyć, że w pierwszej serii, z lat sześćdziesiątych, przyczyną ewolucji małp był sprowadzony przez kosmonautów na Ziemię wirus, który doprowadził do śmierci wszystkich psów i kotów. Ludzie w tęsknocie za zwierzętami udomowili małpy, które z czasem przez naśladownictwo przejęły wszystkie ludzkie kompetencje językowe i społeczne. Po premierze Genezy Planety Matp debatowano na temat prawdopodobieństwa dystopijnej wersji przyszłości przedstawionej w filmach. Zob. m.in. https://www.bbc.com/news/science-environment-28258990 (dostęp: 30.07.2019); oraz https://time.com/2977183/planet-of-the-apes-science/ (dostęp: 30.07.2019).

Prace Kulturoznawcze 23, 2019, nr 2-3

(C) for this edition by CNS 
Peter Singer w komentarzu do teorii fasady Fransa de Waala ${ }^{35}$ stwierdza, że moralność jest kwestią zarówno biologii, jak i kultury; nie będąc cechą wyłącznie ludzką, jest jednak również wynikiem historii ewolucji człowieka ${ }^{36}$. Singer pisze, że powinniśmy założyć, że: „Ludzka natura jest zasadniczo społeczna, a korzenie etyki człowieka tkwią w będących wynikiem ewolucji cechach psychicznych i wzorcach zachowania, które dzielimy z innymi zwierzętami społecznymi, szczególnie naczelnymi" ${ }^{37}$. Na wrodzone, empatyczne zachowania wybranych gatunków zwierząt wskazują także Marc Bekoff i Jessica Pierce ${ }^{38}$. Badania prymatologów pokazują, jak niewiele różnic występuje między ludźmi a małpami człekokształtnymi. Według Singera dostrzeżenie tych wzajemnych podobieństw może przyczynić się do zmniejszenia dystansu między ludźmi a całym światem zwierzęcym, którego reprezentantem jest małpa jako zwierzę najbliżej spokrewnione z człowiekiem. Badania genetyczne wskazują, że między ludźmi, bonobo i szympansami występują niewielkie, zaledwie kilku procentowe rozbieżności genetyczne ${ }^{39}$. Małpa przez swoje podobieństwo do człowieka jest w pewnym sensie „uosobieniem ludzkiej zwierzęcości”. W opowieści o Planecie Małp mamy do czynienia ze specyficznym przykładem z zakresu prymatologii, ponieważ obcujemy tutaj z małpą z przyszłości. Nie z małpą nam współczesną, tą z laboratorium, $\mathrm{z}$ zoo czy żyjącą $\mathrm{w}$ naturze, ani też z małpą z przeszłości, muzealną lub nowo odnalezioną skamieliną, lecz z małpą, która w wyniku spekulatywnej ewolucji staje się simius sapiens na wzór i podobieństwo ludzi.

Przedmiotem dociekań Coco Fusco jest przemoc, nie w dosłownym sensie, ale ukryta ekonomiczna opresja, jakiej bezpośrednio lub pośrednio doświadczamy na co dzień. Wiedzę na temat drapieżnictwa u ludzi dr Zira czerpie z dokumentalnych i fabularnych audiowizualnych przekazów w telewizji i internecie. Natomiast wiedzę o ssakach naczelnych performerka zdobywa między innymi z rozmów z prymatologami, wśród których głównym konsultantem projektu Observations of Predation in Humans był Robert Sapolsky, neurolog z Uniwersytetu Stanforda. Jego kompetencje, ale też zachowanie, sposób frazowania i gestykulacji, były dla artystki wzorem do zaplanowania inscenizacji własnych zachowań jako badaczki (dr Ziry) podczas prowadzenia wykładów ${ }^{40}$. Jedną z głównych inspiracji była dla

35 F. de Waal, op. cit., s. 171-190.

${ }^{36}$ P. Singer, The Expanding Circle, Oxford 1981.

${ }^{37}$ F. de Waal, op. cit., s. 137.

${ }^{38}$ M. Bekoff, J. Pierce, Dzika sprawiedliwość. Moralne życie zwierząt, przeł. S. Szymański, Kraków 2019. Zob. D. Wolska, Zwierze - (w)granica(ch) kultury. Kilka uwag i pytań, „Prace Kulturoznawcze" 14, 2012, nr 2, s. 36.

${ }^{39}$ K. Prüfer, K. Munch, S. Pääbo, The bonobo genome compared with the chimpanzee and human genomes, „Nature” 13.06.2012, s. 527-531, https://www.nature.com/articles/nature11128 (dostęp: 7.08.2019).

${ }^{40}$ Zob. wykład Coco Fusco - CoHosts: Guest Spot \& Coco Fusco, Baltimore School for the Arts 13.01.2014, https://www.youtube.com/watch?v=w_KrKig6IhY (dostęp: 31.07.2019). 
Fusco również książka Barbary Natterson-Horowitz i Kathryn Bowers pod tytułem Zoobiquity $^{41}$, z której to lektury dr Zira wnioskuje, że doświadczane przez ludzi stany będące konsekwencją fizycznych i psychicznych dysfunkcji są podobne do odczuwanych przez naczelne $\mathrm{w}$ niewoli. Ważnym materiałem inspirującym performerkę były też dwie sfilmowane historie: dokument Barbeta Schroedera z 1978 roku zatytułowany Koko: A Talking Gorilla ${ }^{42}$ oraz Projekt Nim Jamesa Marsha z $2011 \mathrm{roku}^{43}$; oba opisujące eksperymenty naukowe zmierzające do nauczenia małp językowej komunikacji z człowiekiem ${ }^{44}$. Przypadek gorylicy Koko i szympansa Nim dowodzą predyspozycji i chęci małp człekokształtnych do nawiązania komunikacji z człowiekiem, niemniej jednak ich niezdolność przystosowania się do „ludzkiego" sposobu życia - opiekunowie obu małp nie potrafili zapanować nad dorosłymi, zamieszkującymi z ludźmi osobnikami — ukazuje bezzasadność i tragizm eksperymentów zmierzających do antropomorfizacji małp ${ }^{45}$.

Lata sześćdziesiąte $\mathrm{XX}$ wieku, w których powstała pierwsza seria filmów o Planecie Małp, to w Ameryce czas konfliktów rasowych, wojny w Wietnamie i narodzin ruchów ekologicznych. Pierwsza część filmowego cyklu jest odzwierciedleniem tych politycznych relacji i wywoływanych przez nie społecznych niepokojów. To również okres prowadzenia relatywistycznych i komparatystycznych badań nad ssakami naczelnymi, w wyniku których na gruncie prymatologii przyjęta zostaje hipoteza umysłu społecznego jako złożonego społecznego konstruktu. Coco Fusco w rewizji poglądów dotyczących podejścia do prowadzenia badań nad ssakami naczelnymi w latach sześćdziesiątych widzi ten sam mechanizm, który doprowadził do zmiany schematów reprezentacji związanych z dyskursem postkolonialnym w kulturze popularnej. Odzyskiwanie podmiotowości w sensie narodowym, etnicznym czy płciowym przebiega tym samym torem co odzyskiwanie podmiotowości gatunkowej. W twórczości Coco Fusco te procesy są z sobą tożsame. Aby wydobyć mniejszościową tożsamość, Fusco musi zwizualizować swoją odmienność, aby „włączyć” ją w siebie. Jak pisze Agamben:

Przyjrzyjmy się nowożytnej maszynie antropologicznej. Funkcjonuje ona — jak widzieliśmy — wykluczając poza siebie jako (jeszcze) nieludzkie to, co już jest ludzkie, czyli animalizując to, co ludzkie, izolując nie-ludzkość w człowieku: homo alalus lub człowieka-małpę. Wystarczy

${ }^{41}$ B. Natterson-Horowitz, K. Bowers, Zoobiquity: The Astonishing Connection between Human and Animal Health, New York 2013.

${ }^{42}$ Koko: A Talking Gorilla, reż. B. Schroeder, Francja 1978.

43 Projekt Nim, reż. J. Marsh, USA-Wielka Brytania 2011.

${ }^{44}$ Zob. http://www.ape-o-naut.org/famous/famous/reallife.html (dostęp: 31.07.2019); oraz https://www.nytimes.com/1995/06/06/science/chimp-talk-debate-is-it-really-language.html (dostęp: 31.07.2019).

${ }^{45}$ Zob. też omówienie eksperymentu jednego z pierwszych prymatologów, Clarence'a Raya Carpentera, który w 1938 roku przeniósł grupę około 400 rezusów z Azji na karaibską wyspę Cayo Santiago, gdzie małpy zaczęły tworzyć struktury społeczne w: D. Haraway, Animal sociology and a natural economy of the body politic: A political physiology of dominance, [w:] idem, Simians, Cyborgs, and Women: The Reinvention of Nature, New York 1991, s. 7-20. 
rozszerzyć nasze pole badawcze kilka dekad wprzód, aby w miejscu tego niewinnego odkrycia paleontologicznego odnaleźć Żyda, czyli nieczłowieka wytworzonego przez człowieka, bądź też neomort czy pacjenta pogrążonego w śpiączce, czyli zwierzę wydzielone w ciele samego człowieka $^{46}$.

Strategia Fusco to wcielenie Innego poprzez jego wizualizację dla innych.

Doktor Zira jako bonobo rozumie wiele z zachowań innych ssaków naczelnych - ludzi. W swoich wykładach w zabawny sposób zadaje pytania o przyczyny agresji i nierówności ekonomiczno-społecznych. Drapieżnictwo ludzi nie jest tu potraktowane jako fizyczne okrucieństwo jednego osobnika względem drugiego, ale analizowane z punktu widzenia relacji z kapitalistycznymi formami zalegalizowanego przymusu oraz przemocą symboliczną. Samica bonobo Zira mówi o drapieżnictwie jako o zorientowanej na cel agresji polegającej na kumulacji i gromadzeniu zasobów ${ }^{47}$. Jolanta Brach-Czaina w tekście Szympans pisze: „stary, sztywny podmiot zostaje zdemaskowany nie po to, aby go unicestwić, lecz powiększyć. Zwycięzca chce wziąć całą pulę [...]. Nie spodziewam się, by filozofia miała nas wykpić" ${ }^{48}$. Taka perspektywa kieruje nas w stronę genocentrycznego redukcjonizmu, w którym filozofia stanowi kolejny, rozszerzony memetyczny układ sprzyjający zasadzie doboru, przystosowania i przetrwania ludzkiego genu; to, co być może pozwoli nam przetrwać zarówno w sensie indywidualnym, jak i gatunkowym ${ }^{49}$. Doktor Zira mogłaby odpowiedzieć, że to sztuka jest jedynym obszarem, który pozwala skutecznie zakpić z produkowanego w antropologicznej maszynie podmiotu.

\section{Zakończenie}

Performance art ma za zadanie działać skutecznie - misyjny charakter tej sztuki jest jej warunkiem sine qua non. Ugruntowanie w aktualnym społeczno-politycznym kontekście, zespolenie twórcy i dzieła w działaniu i zaangażowanie widza w aktywny odbiór tworzy z performansu skuteczne narzędzie oddziaływania. Motywy i argumenty za zmianą performans często znajduje w najnowszej humanistyce, którą się inspiruje, ale i na którą wpływa. Jon McKenzie twierdzi, że nadrzędnym paradygmatem performansu kulturowego jest ciągłe poszukiwanie i podejmowanie nowych przedmiotów badań, nowych działań kulturowych, rozwiązań

46 G. Agamben, op. cit., s. 130.

47, ,[A] broader sense predation means 'to plunder', and in animal psychology it is understood as goal-oriented aggression for the accumulation of resources" - https://www.artforum.com/interviews/coco-fusco-talks-about-her-latest-performance-44278 (dostęp: 31.07.2019).

48 J. Brach-Czaina, Błony umystu, Warszawa 2003, s. 120-121.

49 R. Dawkins, Samolubny gen, przeł. M. Skoneczny, Warszawa 1996. 
organizacyjnych i wynalazków technicznych ${ }^{50}$. Odkrywanie nowych obszarów tematycznych wiąże się ze stosowaniem nowych metod badawczych i twórczych, te zaś potrzebują nowych metafor jako nośników treści. W wyniku tego tworzą się interdyscyplinarne narzędzia, które umożliwiają analizowanie podmiotów dotychczas pomijanych i marginalizowanych, zarówno w sztuce, jak i w nauce. Coco Fusco podejmuje aktualne i często pomijane w debacie publicznej tematy. Jej działalność dotyczy tożsamości etnicznej, kulturowej, płciowej i gatunkowej. W Observations of Predation in Humans: A Lecture by Dr. Zira, Animal Psychologis nakłada maskę zwierzęcia - samicy, po to żeby wyodrębnić z siebie zwierzę, którym jest, i uczynić je widzialnym. Dokonuje tym samym podwójnego przekroczenia, gatunkowego i płciowego, ponieważ myśląc o małpie, stajemy przed specyficznym problemem dysonansu poznawczego — małpa nie może być przecież kobietą. Kiedy zwraca się do nas małpa, jej „wygląd jest groteskowy, kształt — odpychający, profil — zwierzęcy, zapach — odrażający, a kolor skóry — wstrętny" ${ }^{51}$. Polityka małpiego spojrzenia to misja wizualizacji obecności słabych i wykluczonych. To gest zniesienia granicy między animalizacją człowieka a humanizacją zwierzęcia. Działanie, które zmierza ku zredukowaniu podziału, w warunkach, w których przekroczenie nie następuje ani w stronę animalizacji człowieka, ani też antropomorfizacji zwierząt, lecz w stronę zniesienia klasyfikacji, która oba te porządki ustanawia. Coco Fusco, nakładając maskę małpy, niweluje granicę między swoim kulturowo ludzkim i biologicznie nie-ludzkim wnętrzem a zewnętrznym wizerunkiem małpy, przebranej za kobietę naukowca. Naruszenie granicy jest możliwe wyłącznie w kontekście tego konkretnego działania. Wspólna przestrzeń wewnętrznego spotkania między performerką, małpą i kobietą powstaje dzięki performatywnemu aktowi przekroczenia dokonującemu się w działaniu twórczym, zmierzającym do rozpoznania w sobie tego, co ludzkie i nie-ludzkie. Linia podziału między trzema tożsamościami - performerką jako żeńskim osobnikiem Homo sapiens, performerką jako samicą człekokształtnej małpy i samicą bonobo jako kobietą naukowcem — odnowi się po ściągnięciu maski. Misja Coco Fusco polega na produkcji potrzeby choć chwilowego zawieszenia tej granicy. W świetle takiej interpretacji, parafrazując Agambena: „Performowanie jest [...] czymś więcej niż zwykłym obalaniem i znoszeniem separacji - to poszukiwanie dla niej nowych zastosowań, nauka igrania $\mathrm{z}$ istniejącymi formami rozdziału" 52 .

50 J. McKenzie, Performuj albo... Od dyscypliny do performansu, przeł. T. Kubikowski, Kraków 2011, s. 362.

51 P. Boulle, op. cit., s. 113.

52 Cytat w oryginale brzmi: „Profanowanie jest [...] czymś więcej niż zwykłym obalaniem i znoszeniem separacji - to poszukiwanie dla niej nowych zastosowań, nauka igrania $\mathrm{z}$ istniejącymi formami rozdziału" - G. Agamben, Profanacje, przeł. M. Kwaterko, Warszawa, 2006, s. 110, cyt. za: A. Żychliński, Zwierzę, którego nie ma. Experimentum de hominis natura, „Konteksty. Polska Sztuka Ludowa" 2009, nr 4, s. 59. 


\section{Performative missions of the simius sapiens: Coco Fusco on the Planet of the Apes}

Abstract

The article examines performances of the Cuban-born artist Coco Fusco, who in her interdisciplinary projects raises issues related to national, ethnic, gender and genre identity. In a series of performances entitled Observations of Predation in Humans: A Lecture by Dr. Zira, Animal Psychologist from 2013, Fusco, inspired by the history of the Planet of the Apes film series and the latest research in primacy, takes on the role of Dr. Zira to teach anthropology from a non-human perspective, as a chimpanzee.

Keywords: performance art, primacy, documentation and visualization strategies in performance art, Coco Fusco

\section{Bibliografia}

Agamben G., Otwarte, przeł. P. Mościcki, „Krytyka Polityczna” 2008, nr 15.

Bakke M., Pandemiczne wspólnoty przenoszone droga plastikowa, [w:] Pandemia. Nauka, sztuka, geopolityka, red. M. Iwański, J. Lubiak, Szczecin 2018.

Bekoff M., Pierce J., Dzika sprawiedliwość. Moralne życie zwierząt, przeł. S. Szymański, Kraków 2019.

Boulle P., Planeta matp, przeł. K. Pruska, K. Pruski, Warszawa 1980.

Brach-Czaina J., Błony umystu, Warszawa 2003.

Braidotti R., Four theses on posthuman feminism, [w:] R. Grusin, Anthropocene Feminism, Minneapolis 2017.

Cavalieri P., Singer P., The Great Ape Project: Equality Beyond Humanity, New York 1994.

Dawkins R., Samolubny gen, przeł. M. Skoneczny, Warszawa 1996.

Fusco C., The Bodies That Were Not Ours: And Other Writings, London-New York 2001.

Fusco C., On-line simulations/real-life politics A discussion with Ricardo Dominguez on staging virtual theatre, „TDR/The Drama Review” 47, 2003, nr 2.

Goodman M., Czelusniak J., Page S., Meireles C.M., Where DNA sequences place Homo sapiens in a phylogenetic classification of primates, [w:] J. Moggi-Cecchi, M.A. Raath, P.V. Tobias, G.A. Doyle, Humanity from African Naissance to Coming Millennia, Firenze 2001.

Haraway D., Animal sociology and a natural economy of the body politic: A political physiology of dominance, [w:] idem, Simians, Cyborgs, and Women: The Reinvention of Nature, New York 1991.

Haraway D., Primate Visions: Gender, Race, and Nature in the World of Modern Science, New York-London 1989.

Hickok G., Mit neuronów lustrzanych, przeł. K. Cipora, A. Machniak, Kraków 2016.

Human Zoos: Science and Spectacle in the Age of Colonial Empires, red. P. Blanchard, N. Bancel, G. Boëtsch, É. Deroo, S. Lemaire, C. Forsdick, Liverpool 2008.

Massumi B., Autonomia afektu, przeł. A. Lipszyc, „Teksty Drugie” 2013, nr 6.

McKenzie J., Performuj albo... Od dyscypliny do performansu, przeł. T. Kubikowski, Kraków 2011.

Nalewajk Ż., Ironia jako alternatywa rozpaczy. Krytyka kultury w Sprawozdaniu dla Akademii Franza Kafki, „Tekstualia” 2008, nr 3.

Prace Kulturoznawcze 23, 2019, nr 2-3

(C) for this edition by CNS 
Natterson-Horowitz B., Bowers K., Zoobiquity: The Astonishing Connection Between Human and Animal Health, New York 2013.

Prüfer K., Munch K., Pääbo S., The bonobo genome compared with the chimpanzee and human genomes, „Nature” 28.06.2012, https://www.nature.com/articles/nature11128 (dostęp: 7.08.2019).

Przybysz P., Wprowadzenie. Poznanie spoleczne: lustrzane neurony, automatyzm a refleksje, rozpoznawanie umysłów, [w:] Formy aktywności umystu. Ujęcia kognitywistyczne, t. 2, red. A. Klawiter, Warszawa 2009.

Radical Presence: Black Performance in Contemporary Art, red. Y. Backer, N. Beckwith, F. Sirmans, V.C. Oliver, Houston 2013.

Sánchez-Gómez L.A., Human zoos or ethnic shows? Essence and contingency in living ethnological exhibitons, „Culture \& History Digital Journal” 2, 2013, nr 2.

Singer P., Etyka praktyczna, przeł. A. Sagan, Warszawa 2003.

Singer P., The Expanding Circle, Oxford 1981.

Singer P., Wyzwolenie zwierząt, przeł. A. Alichniewicz, A. Szczęsna, Warszawa 2004.

Waal F. de, Matpy i filozofowie. Skąd pochodzi moralność, przeł. B. Brożek, M. Furman, Kraków 2019.

Westfahl G., The Greenwood Encyclopedia of Science Fiction and Fantasy: Themes, Works, and Wonders, t. 1, London 2005.

Wolska D., Zwierzę - (w)granica(ch) kultury. Kilka uwag i pytań, „Prace Kulturoznawcze” 14, 2012 , $\mathrm{nr} 2$.

\section{Źródła internetowe}

http://www.ape-o-naut.org/famous/famous/reallife.html.

https://www.bbc.com/news/science-environment-28258990.

https://www.cocofusco.com/menu.

https://www.cocofusco.com/two-undiscovered-amerindians.

https://www.dailyserving.com/2015/02/from-the-archive-coco-fusco-observations-of-predation-in-

humans-at-the-studio-museum-in-harlem/.

https://frieze.com/article/six-things-we-learned-dr-zira.

https://www.moma.org/calendar/exhibitions/2220?locale=en.

https://www.nytimes.com/1995/06/06/science/chimp-talk-debate-is-it-really-language.html.

http://www.raimundhoghe.com/fr/fr_handicaps.html.

https://time.com/2977183/planet-of-the-apes-science.

https://walkerart.org/magazine/coco-fusco-guerrilla-girls.

https://walkerart.org/magazine/coco-fusco-planet-of-the-apes.

https://www.youtube.com/watch?v=EHVBZh5HBgc\&eurl=http\%3A\%2F\%2Fwww.woostercol-

lective.com $\% 2 \mathrm{~F} \% 2 \mathrm{~F}$.

https://www.youtube.com/watch?v=w_KrKig6IhY.

\section{Filmografia}

Geneza planety matp, reż. R. Wyatt, USA 2011.

Planeta matp, reż. F.J. Schaffner, USA 1968.

TED Ethology: Primate Visions of the Human Mind, reż. Coco Fusco, USA 2015.

Ucieczka z Planety Matp, reż. D. Taylor, USA 1971.

W podziemiach Planety Matp, reż. T. Post, USA 1970.

Prace Kulturoznawcze 23, 2019, nr 2-3

(C) for this edition by CNS 